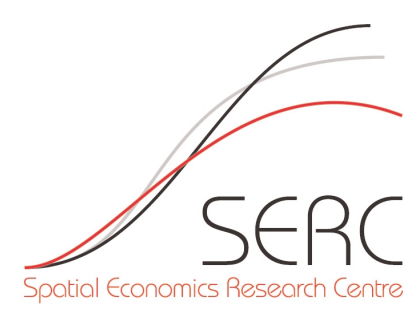

SERC DISCUSSION PAPER 104

\title{
Great Britain's Second-Order City Regions in Recessions, 1978-2010
}

Tony Champion (SERC, CURDS)

Alan Townsend (Department of Geography, University of Durham)

April 2012 
This work is part of the research programme of the independent UK Spatial Economics Research Centre funded by a grant from the Economic and Social Research Council (ESRC), Department for Business, Innovation \& Skills (BIS) and the Welsh Assembly Government. The support of the funders is acknowledged. The views expressed are those of the authors and do not represent the views of the funders.

(C) T. Champion and A. Townsend, submitted 2012 


\section{Great Britain's Second-Order City Regions in Recessions, 1978-2010}

\section{Tony Champion* and Alan Townsend**}

\section{April 2012}

* SERC and Centre for Urban and Regional Development Studies (CURDS), Newcastle University

** Department of Geography, University of Durham

Acknowledgements

The data derived from the Business Register Employment Survey (BRES) and its predecessors were extracted from the National On-line Manpower Information System (nomisweb.co.uk) under a Notice issued by the Office for National Statistics (ONS) in September 2011, reference NTC/BRES10-S0122. 


\begin{abstract}
$\underline{\text { Abstract }}$
While it is now accepted that the 2008-09 recession accentuated regional differences in Britain, it is more difficult to identify the role of major cities, especially over a longer time scale. Using previously established methods focussed on employment, this paper assesses the record of nine city regions in the 2008-09 recession, both in its own right and in comparison with the previous two recessions. The 2008-09 recession is found to have impacted the nine city regions less than the previous ones in absolute terms but not in relative terms compared with the London city region or the rest of Britain. Over the whole period from 1978, the paper has found the city regions to be fairly tightly in the grip of national cyclical trends of recession and recovery, but generally performing less resiliently than Britain as a whole. In comparison, London showed appreciably more cyclical behaviour between 1989 and 2002 than at other times, with the most remarkable recovery from recession in this period. The public sector helped the performance of second-order city regions from 1997 to 2010, including the peak of growth rates in city regions and their cores in 1998-2002, but its employment reductions will dominate the prospects for provincial cities for several years to come.
\end{abstract}

Keywords: Recession, resilience, employment change, second-order city, city region, Great Britain

JEL Classifications: J21, O18, R11, R12 


\section{Introduction}

The past four decades have brought major changes to the space economy of the UK, with recessions, de-industrialisation and counterurbanisation posing particular challenges for the larger cities of the northern half of the country (Champion and Townsend, 1990; Coe and Jones, 2010). In the recent past, however, considerable efforts were made to counter urban decline, including the policies adopted following the Urban Task Force's report Towards an urban renaissance (Rogers Report, 1999) and the formation of the Core Cities Group to lobby for more support for England's eight largest provincial cities. These sorts of interventions met with substantial success according to a variety of assessments, and 'There has been a sea change in how cities are regarded' (Parkinson et al., 2006, page 9), more recently with the Coalition government establishing a Minister for Cities and a policy paper on their growth (HM Government, 2011).

But even before the major recession starting in 2008, questions were being raised about the scale and consistency of this resurgence. Despite coming after a decade of recovery from the 1990-93 recession, the State of the English Cities Report (ODPM, 2006) had to conclude that the scale of growth for urban England overall had been only modest and patchy: London and most other cities in the south and east had generally performed better than those in the north and west, which were still lacking sustainable growth. Taking the story on employment change through to the final stages of the boom in 2007 for England's Core Cities and their city regions, Champion and Townsend (2011) showed that, in aggregate, these had been consistently outpaced by London except during the dot-com recession. Their strongest performance relative to England as a whole had occurred around the turn of the century, but even then their overall growth had barely matched the national rate and subsequently it had dropped back from it again.

The onset of the banking crisis in 2007 and the official recession of 2008-09 (Bell and Blanchflower, 2010; ESRC, 2009; ONS, 2011) have greatly altered the context for Britain's second-order cities and raised a major question about the very sustainability and survival of the progress which they had made in the previous boom period. Initial 
speculation that London would be most severely impacted owing to its dominant position in the UK's financial sector was quickly replaced by the realisation that the 'credit crunch', which occurred in spite of the government's support for the banks, had the effect of undermining investment plans across wide swathes of the national economy (see, for instance, Clayton, 2011; Lee, 2009). How, therefore, have the second-order cities fared in the face of the sharpest cutback in national output since the Great Depression of the 1930s and does this provide any pointers as to their future prospects?

After considering the theoretical background, the main focus of the paper is on change between 2007 and 2010, starting with a set of indicators that measure the labourmarket impacts of the 2008-09 recession. Then we use a subset of these to compare this recent experience with the impacts of the two previous national recessions. For the latter, the paper takes advantage of a dataset compiled for a previous study of employment change for England's larger city regions (Champion and Townsend, 2011) that critiqued the Core Cities Group's (2004) claim that 'Our cities are back', but extends it temporally to cover the post-2007 recession and geographically to include the largest second-order city outside England, namely Glasgow. Finally, the paper examines the changed industrial structure of the second-order city regions in order to assess their relative resilience in the future.

\section{Background}

Three bodies of literature are most relevant to the questions which this paper seeks to answer. The first of these concerns the theoretical debates about the relative weakness of second-order cities in national settlement systems compared to the first-order layer, which in most countries comprises a single city which is also the national capital, and also vis-à-vis smaller cities, towns and more rural regions (ESPON, 2011). The latter were seen as posing the major challenge to both first- and second-order cities through most of the second half of the twentieth century (see, for instance, Champion, 1989). More recently, attention has switched to the 'resurgent city' thesis where the new knowledge-based economy is seen to favour agglomeration forces that privilege a 
relatively small number of global cities over both second-order cities and the lower levels of the settlement hierarchy (see, for instance, Cheshire, 2006; Krugman, 1996; Scott, 2001). This broad body of literature adopts a relatively long-term perspective that equates most closely with the deep-structural processes that Fielding (1993) employed to understand regional economic shifts 1950-1990 and sees its most recent expression in the form of evolutionary economic geography (see, for instance, Boschma, 2004; Martin and Sunley, 2007).

A second set of literature is primarily addressed to the shorter-term fluctuations in the relative strength of regional and local economies, whilst also being set within a consideration of longer-term trends. Labelled the layer of 'conjoncture' by Fielding (1993), this is focused on business cycles and the related boom/bust oscillations in labour and housing markets. Deriving largely from ecological theory, the main emphasis currently is on the notion of 'resilience' in the face of economic downturn and on the way in which 'path dependency' may influence how far an economy regains its pre-recession level or alternatively leaps forward into a new dynamic (Christopherson et al., 2010; Dawley et al., 2010; Martin and Sunley, 2006). In particular, Martin (2012) shows how the concept of resilience can be combined with that of 'hysteresis' to examine how regional economies react to recessionary shocks. This approach not only aims to see the extent to which regions differ in their ability to rebound from such shocks but also to discover whether regions that are more severely affected tend to grow more slowly than other regions as a result. Can major recessions lead to a permanent upward shift in an economy's rate of unemployment? A major recession increases the likelihood of long term unemployment, which in turn erodes a worker's skills, dents his or her employability, and increases their dependency on welfare benefits, all thereby reducing an unemployed person's prospects of being reemployed even when the economy recovers (Martin, 2012). As a result, the unemployment rates of major areas may not return to their pre-recession rates.

The third set comprises empirical studies of the spatial impact of recession and the policy responses prompted by differential growth through economic cycles. This literature tends to be nationally specific and certainly includes a great deal on the UK. Here, while over the years there has been some consideration of the urban-rural dimension (see, for instance, Champion and Townsend, 1990; Fothergill and Gudgin, 
1982), the primary focus has been and continues to be on the so-called 'north/south divide' (Rowthorn, 2010; Smith, 1989; Ward, 2011). Changes in the nature and location of the divide have greatly exercised both academics and policymakers ever since the Great Depression of 1930-34 impacted most severely on the coalmining and heavy-industry areas in Scotland, Wales and the northernmost parts of England and led to the origins of regional policy assisting these areas. Following the 'full employment' era of the early postwar years, the downturns in the 1960s and 1973-76 began showing up the underlying weaknesses of the textile-based regions of Lancashire and West Yorkshire and shipbuilding areas of Merseyside, Tyneside and Clydeside, but it was the early 1980s recession that was critical in marking out the new geography of Britain, as it took its toll on the full swathe of the manufacturing sector and dragged the dividing line south of the West Midlands conurbation (see, for instance, Lewis and Townsend, 1989; Townsend, 1983). The extent of this 'expanded north' has altered little in the quarter of a century since then, despite the London region being hit hardest by the 1990-93 recession and the majority of northern cities seeing overall job growth during the subsequent recovery (Champion and Townsend, 2011; Parkinson et al., 2006).

The literature available so far on the impact of the 2008-09 recession (see, for instance, Bell and Blanchflower, 2010; Clayton, 2011; ippr north, 2009; LSE, 2011; ONS, 2011; Wickham, 2010; Work Foundation, 2010), suggests that it is largely reinforcing the north/south divide, despite initial expectation that the banking crisis would impact most severely on London. Early commentators were no doubt influenced by the fact that the short-lived 'dot com' recession of 2001 knocked London back somewhat but had little impact on the rest of the country (Champion and Townsend, 2011). The latest downturn, however, is now seen to have affected a much wider section of the economy as a result of the so-called 'credit crunch'. Indeed, because of swift action by central government and the Bank of England in support of the ailing banks, the immediate impact on jobs fell much less on the financial sector than on the other sectors that rely on abundant and preferably cheap borrowing to finance their business operations and investment plans.

It is against this background that the present study has been framed. It tackles the question of whether Britain's second-order cities are becoming more resilient in the 
face of recession. In more detail, have their city regions been less impacted by the 2008-09 recession than previous ones by comparison with the London region and the rest of the country? In similar vein but at a more local level, have their cores fared better than the rest of their own city regions? Positive answers to both these questions would lend support to headlines such as 'cities as drivers of regional development' (EU Regional Policy, 2009, page 18) and 'core cities driving recovery' (Core Cities Group, 2010, title page). Any different answer would raise policy questions about the scale and nature of renewed government support for these cities and conceivably their regions (as advocated by Centre for Cities, 2011; Lee et al, 2009; Ward, 2011) as opposed to anticipating a 'two-nation recovery' (Brinkley, 2011; Work Foundation, 2011) and instead quietly allowing their managed decline, as suggested most baldly by the Policy Exchange (Leunig and Swaffham, 2008; Morton, 2011).

\section{Analytical approach}

Two sets of methodological decisions had to be made at the outset of this study. One concerned identifying the cities to be included in the study and how each of them should be delineated on the ground. The other involved the choice of the types of measures to be used for calibrating the impact of the recession as well as the selection of data sources for these. In both cases, we have opted to build on the approach used in our previous work on assessing the record of economic regeneration of England's second-order cities up to 2007 (Champion and Townsend, 2011), while at the same time including several additional indicators of recent trends.

In terms of the second-order cities included in the study, the previous study focused on the eight English cities which, following the election of the 'New Labour' government in 1997, formed the Core Cities Group to lobby for greater public-sector investment to counterbalance the preferential treatment that their members reckoned London was receiving at the time and which are also the subject of HM Government (2011). These comprise Birmingham, Bristol, Leeds, Liverpool, Manchester, Newcastle upon Tyne, Nottingham and Sheffield. For the present study, we extended the research to the whole of Great Britain and added its other main provincial 
conurbation, Glasgow, to this list. As regards delineating each city, a city-region approach was adopted, with the definitions being those used by the Core Cities Group for its own economic and labour market analyses (CURDS, 1999) and with the same principles (including using local authority areas as building blocks) being applied to Glasgow and also to London, which serves as the main comparator (see Figure 1).

Figure 1. The City Regions

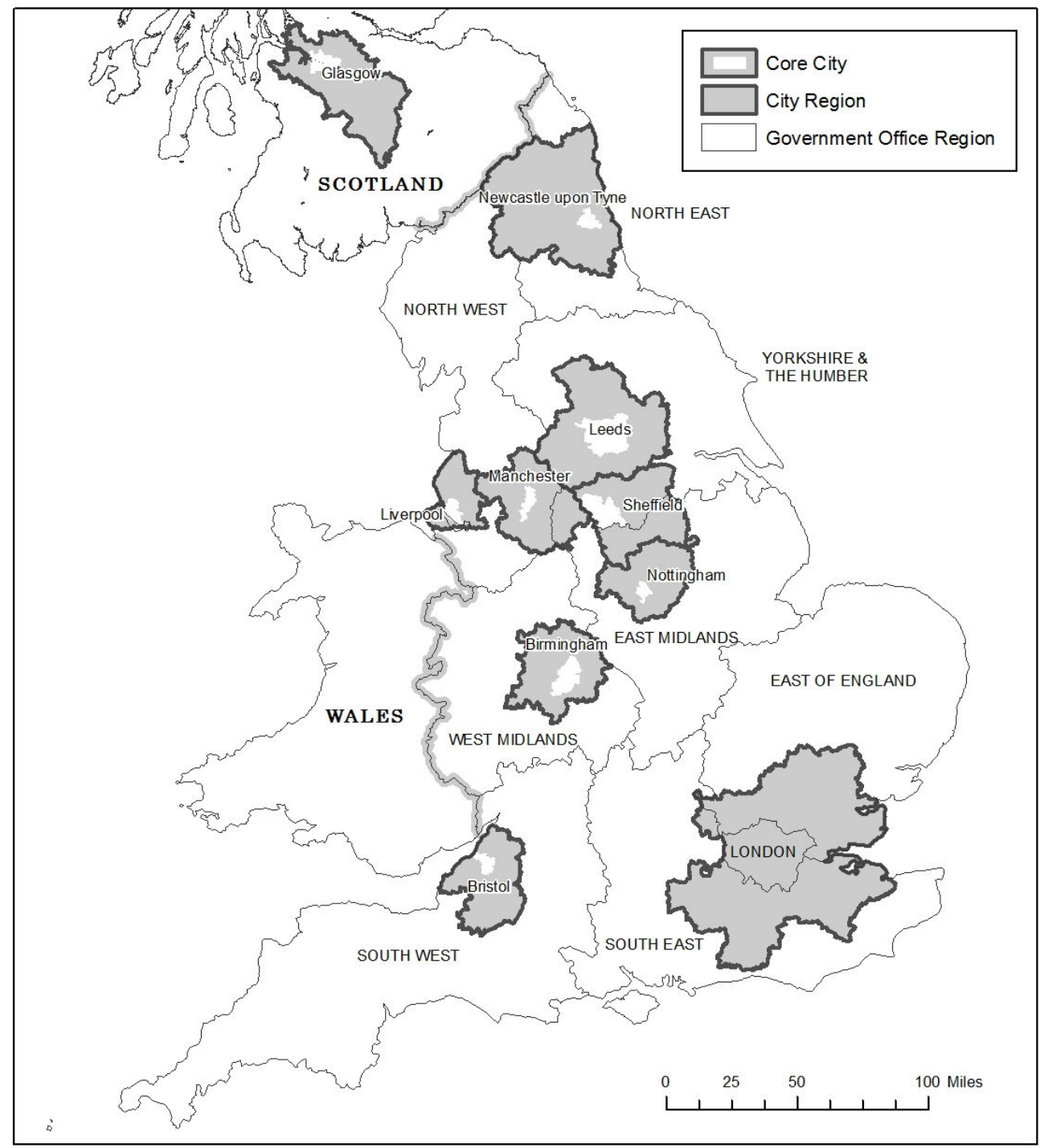

As regards the measures, we had a wider range of options than in our previous study, at least for examining the impacts of the 2008-09 recession on these second-order cities. As the main aim then was to compare the performance of these cities relative to London and the rest of the country over a long period to assess how far the Core 
Cities were really 'back' (see above), we needed a relevant data set that would provide a robust and internally consistent sub-national series back to the early 1980s. In fact, this was also a requirement for comparing the impact of this recession with that of previous economic downturns, so for that purpose we were again unable to use the claimant-based unemployment data (because its basis has altered over time and also because it does not include everyone who is seeking work) nor data from the Labour Force Survey (because until recently it operated an insufficiently large sample size for local-area estimates). Instead, we again used the record of change in employment provided by the Annual Business Inquiry (ABI), along with its predecessors - the Annual Employment Survey (1991-98) and Census of Employment (pre-1991) - and with its successor (from 2008), the Business Register Employment Survey (BRES). Nevertheless, given the more recent changes in the Labour Force Survey, including its incorporation within the larger Annual Population Survey (APS), we were able to use this for seeing how our cities fared in the 2008-09 recession, including its information on people seeking work as well as on workers.

Neither of our chosen data sources, however, is trouble-free. The APS's small sample size poses a particular challenge when analysing change at sub-regional scale over a relatively short time-period like the six quarters between the peak and trough of economic activity in the 2008-09 recession. Our main response is to treat the 9 second-order city regions as a single aggregate and make sub-national comparisons with just the London city region and the whole of the rest of the country, these three zones making up 28, 25 and 47 per cent of Great Britain's total employment respectively. By contrast, the employment data from BRES and its predecessors draw on a full survey of larger employers (though only a sample of smaller ones) and have the additional advantage that they include every job, thereby capturing the effect of a person changing from having one part-time job to more than one and vice versa. Among several downsides, however, variations can occur over time in the precise locations at which multi-site firms code their workforce, self-employed persons have been excluded until very recently and before 1995 the frequency was less than annual. Also, as reflected in its variety of names over the years (see above), the survey methodology has altered on several occasions, posing a considerable challenge for compiling a consistent time series of data. This latter is, however, one that we have devoted much effort to, along with converting data to deal with periodic changes in 
the Standard Industrial Classification (see Appendix for more detail) - which is why we feel that this source provides the best basis for comparing the economic impact of the last few recessions at sub-regional scale and is robust enough for looking at the city regions individually and also for comparing the performance of their cores and outer areas.

\section{Differential impacts of the recession of 2008-09}

This section presents our findings on the impact of the 2008-09 recession on Britain's 9 second-order city regions compared to the two broad comparator areas of the London city region (the only first-order city) and the rest of the country besides these 10 city regions. Have they maintained their fairly longstanding position of faring worst owing to inherited structural disadvantage or through lacking both the agglomeration economies of the national capital and the cost and environmental advantages of the lower orders of the urban hierarchy and rural areas, or have the regeneration efforts and economic restructuring of the recent past put them on a new footing? We draw on the two sources introduced above.

\section{Evidence from the APS}

The APS-derived data on Great Britain in the final column of Table 1 sets the context for our sub-national analyses of the impact of the 2008-09 recession. As the relevant data are available only on an averaged basis for the previous 12 months, our datum point is for the year ending September 2008, which has a mid-point of March 2008 when the numbers in work peaked nationally. This is compared with data for the year to September 2010 with a mid-point of March 2010, the low point in national employment. By then it can be seen that the national unemployment rate stood at 7.8 per cent of the economically active population of working age, an increase of 2.4 percentage points on the situation two years earlier. The employment rate, calculated with respect to the total population of working age, had fallen by a similar amount, and there had been a reduction in the proportion of workers putting in long hours. 
Table 1. The impact of the 2008-09 recession: evidence from the APS

\begin{tabular}{|c|c|c|c|c|}
\hline Indicator & $9 \mathrm{CRs}$ & $\begin{array}{c}\text { London } \\
\text { CR }\end{array}$ & $\begin{array}{c}\text { Non-CR } \\
\text { Britain }\end{array}$ & $\begin{array}{c}\text { Great } \\
\text { Britain }\end{array}$ \\
\hline \multicolumn{5}{|l|}{ Unemployment rate for $16-64$} \\
\hline all persons $2010 \%$ & 9.3 & 7.9 & 6.9 & 7.8 \\
\hline all persons $2008-10 \%$ pt change & 3.0 & 2.1 & 2.2 & 2.4 \\
\hline males $2008-10 \% p t$ change & 3.7 & 2.3 & 3.1 & 3.1 \\
\hline \multicolumn{5}{|l|}{ Employment rate $16-64$} \\
\hline all persons $2010 \%$ & 67.5 & 70.6 & 72.0 & 70.4 \\
\hline all persons $2008-10 \%$ pt change & -2.6 & -1.6 & -2.3 & -2.2 \\
\hline males $2008-10 \%$ pt change & -3.8 & -2.2 & -3.3 & -3.3 \\
\hline \multicolumn{5}{|l|}{ Working 45 or more hours a week } \\
\hline all persons $2010 \%$ & 21.3 & 29.2 & 23.6 & 24.2 \\
\hline all persons $2008-10 \%$ pt change & -1.7 & -0.4 & -1.8 & -1.4 \\
\hline males $2008-10 \% p t$ change & -2.9 & -0.6 & -2.5 & -2.2 \\
\hline \multicolumn{5}{|l|}{ Change in numbers in work $2008-10 \%$} \\
\hline all persons & -3.0 & 0.3 & -2.8 & -2.1 \\
\hline male & -4.2 & 0.0 & -4.1 & -3.2 \\
\hline female & -1.6 & 0.6 & -1.3 & -1.0 \\
\hline self-employed & -1.7 & 6.7 & -0.3 & 1.2 \\
\hline high-skill (occs 1+2) & 2.7 & 3.9 & 0.5 & 2.0 \\
\hline low-skill (occs 5+8+9) & -7.5 & -5.5 & -6.0 & -6.4 \\
\hline full-time & -4.7 & -1.6 & -4.4 & -3.8 \\
\hline part-time & 2.2 & 7.1 & 1.7 & 2.9 \\
\hline \multicolumn{5}{|l|}{ Change in FTEs $2008-10 \%$} \\
\hline all persons & -3.7 & -0.6 & -3.5 & -2.9 \\
\hline male & -5.0 & -0.9 & -4.8 & -4.0 \\
\hline female & -1.9 & -0.1 & -1.5 & -1.3 \\
\hline
\end{tabular}

Note: The data are for the 12 months ending in September of the year indicated; CR City Region; occs occupations: $1=$ managers and senior officials, $2=$ professional, $5=$ skilled trades, $8=$ process, plant and machine operatives, $9=$ elementary.

Source: calculated from APS. Crown copyright data.

The most direct labour-market-related measure of change in the level of economic activity is provided by Table 1's data on numbers in work, because these are not affected by change in non-working people's self-reported attitude to whether or not they are seeking work (which can vary with stage in the economic cycle) nor by change in population size (most notably through fluctuation in net international migration). The national data reveal a fall of 2.1 per cent in numbers working, but this translates into a cutback of 2.9 per cent in the amount of work done when using fulltime equivalents (FTEs) to allow for the overall switch from full-time to part-time working. In all this, the impact was greater on males than on females. Indeed, a net increase of predominantly female public sector professional workers in health and education helps to explain why the total numbers in high-skill work actually increased over this two-year period. The rise in self-employment can, as in previous recessions, 
be interpreted partly as the result of redundant employees setting up on their own account.

Turning to the sub-national breakdown in Table 1, the overall picture is very clear: the second-order cities in aggregate were the most poorly placed of the three parts of Britain at the end of the recession and their situation had deteriorated during it. Unemployment, for example, averaged 9.3 per cent for the 12-month period ending in September 2010 compared to national figure of 7.8 per cent, with London only marginally above the latter and the rest of the country well below it. Compared to the immediate pre-recession year, the rate for the second-order cities was up by 3 percentage points, compared to a rise of only just over 2 for both London and the noncity-region remainder. The contrast between the second-order cities and London was particularly stark for males, with a percentage point increase more than half as much again as the capital. Moreover, according to the data for the 9 second-order cities individually (not shown here), it is the longstanding economic problem areas that were hardest hit by this recession, with increases in male unemployment rate of 6.0 percentage points for Glasgow, 4.9 for Newcastle, 4.4 for Birmingham and 4.0 for Liverpool, leaving all these with rates in excess of 11.5 per cent for 2009-10.

Most of the other indicators in Table 1 paint a similarly depressing picture for the second-order cities. Over the two-year period their percentage point falls in the four measures relating to employment rate and working 45 or more hours a week were greater than for all those for London and also greater than the non-city-region remainder of Britain for all but one of these. Similarly, the other two parts of the country were generally less impacted in terms of reductions in their work inputs, whether counting FTEs or numbers of people. Even their faster growth of numbers working part-time than for the non-city-region part of Britain can be seen as a weakness alongside the big cutback in full-time working, indicating a larger switch from the latter to the former than elsewhere. The sole bright light for the second-order cities was that their numbers of people working in high-skill jobs grew faster than the national average, this being primarily a structural effect connected with their higher dependence on the public sector, still expanding at this point (see below). 


\section{Evidence from the ABI/BRES}

Turning to the ABI/BRES data, we report in Table 2 only the overall measure of amount of work as represented by FTEs, calculated - in the absence of information on hours worked - on the basis of two part-time jobs equating with one full-time one on average, as in Champion and Townsend (2011). As the data refer to one specific time point each year, we look at change between September 2007 and September 2010 as this three-year period spans the onset and end of the time when national employment was declining (see above). Finally, for the reasons set out in Appendix 1, we omit the industrial grouping that includes agriculture. On this basis, the 9 second-order city regions combined possessed 323,000 fewer FTEs in 2010 than three years earlier. This represents fully 40 per cent of the FTEs lost nationally then, much higher than their 28 per cent share of the country's FTEs, and a reduction of 4.9 per cent, confirming their weakness relative to the rest of the Britain, especially London.

Table 2. The impact of the 2008-09 recession on employment: evidence from the $A B I / B R E S$

\begin{tabular}{lrrr}
\hline City Region (CR) & 2010 & $2007-10$ change & \\
\cline { 2 - 4 } & $000 s$ & $000 s$ & $\%$ \\
\hline Great Britain & 21699 & -799 & -3.5 \\
& & & \\
London CR & 5386 & -122 & -2.2 \\
Non-CR & 10111 & -354 & -3.4 \\
9 CRs & 6202 & -323 & -4.9 \\
& & & \\
Bristol CR & 476 & 8 & 1.8 \\
Leeds CR & 958 & -32 & -3.2 \\
Nottingham CR & 411 & -16 & -3.8 \\
Sheffield CR & 545 & -25 & -4.3 \\
Manchester CR & 1057 & -49 & -4.5 \\
Newcastle CR & 541 & -30 & -5.3 \\
Liverpool CR & 504 & -29 & -5.5 \\
Glasgow CR & 665 & -58 & -8.0 \\
Birmingham CR & 1046 & -91 & -8.0 \\
& & & \\
9 Cities & 2175 & -96 & -4.3 \\
9 CR Remainders & 4027 & -227 & -5.4 \\
\hline Note: Data are on basis of Full Time Equivalents for all sectors bar Farming, forestry and fishing and \\
are for September of the year indicated. \% is the compounded rate derived from the three annual rates \\
of change. '9 cities' refers to the local authorities after which each of the 9 city regions is named. \\
Source: calculated from ABI/BRES. & & & \\
& & &
\end{tabular}


The remainder of Table 2 looks in more detail at the second-order city regions, using two types of breakdown. First, looking at each of the nine separately, it can be seen that only one of them exceeded London's performance, unsurprisingly Bristol, which actually increased its FTE numbers between 2007 and 2010. Second-placed Leeds was previously seen as an exemplar of northern office growth but now failed to match London and barely exceeded the rate for the non-city-region remainder of Britain, while third-placed Nottingham fell below both this and the national level of 3.5 per cent. At the other end of the scale, the FTE numbers for Birmingham and Glasgow were fully 8 per cent lower in 2010 than they had been in 2007, with the next poorest performers being Liverpool and Newcastle. As seen above from the unemployment data, not only are the second-order cities continuing to prove less resilient as a group but the traditionally weakest places were continuing to be worst impacted, confirming the APS-based evidence (see above).

The other disaggregation contrasts the aggregate performance of the main local authority area of each of the nine with that of the rest of their city regions. A major finding of our previous work was that in most periods the latter showed a better employment record than the cores. Here a different note is struck, with their cores not being as badly hit by recession as their more outlying parts. The cores' FTEs went down by 4.2 per cent over the three-year period compared to the 5.3 per cent fall registered by the city-region remainders. Given the long-term tendency towards urban decentralization mentioned earlier, this provides some evidence of the somewhat greater resilience of the 'city' element of the city regions in recession due to a relatively greater dependence on service employment jobs, but their shrinkage is still greater than 3.4 per cent of the aggregate of the smaller cities, towns and rural areas that make up the rest of Britain.

Which sectors were primarily responsible for the second-order city regions' losses between 2007 and 2010? Manufacturing was the largest single contributor, dropping by 122,000 FTEs, a reduction of 14.0 per cent. Construction was the next largest absolute loser, down by 97,000 FTEs, but as this sector was less than half the size of the manufacturing sector in 2007, this represents a larger relative reduction, 24 per cent over the three-year period. Employment in distribution, hotels, etc., fell by 78,000 or 5.8 per cent, and banking, finance and insurance by only 58,000 or 4.3 per 
cent. By contrast, public administration, education and health were 43,000 higher in 2010 than in 2007, an increase of 2.4 per cent.

Did any of the second-order city regions' sectors perform more strongly than the norm? Figure 2 compares their aggregate change rates with those for Britain as a whole as well as with the other two parts of the country. It can be seen that their performance was weaker than average in all sectors except transport and communications. In four of the seven sectors it was weaker than those of both the London city region and the rest of Britain, these being manufacturing, construction, distribution and public administration. Though the latter actually grew over this threeyear period in all three parts of the country, theirs was the lowest growth rate and London's the highest.

Figure 2. Change in FTEs, 2007-10 (\% for period), by sector for 9 City Regions, London City Region, Rest of Great Britain and Great Britain (source: calculated from $A B I / B R E S)$

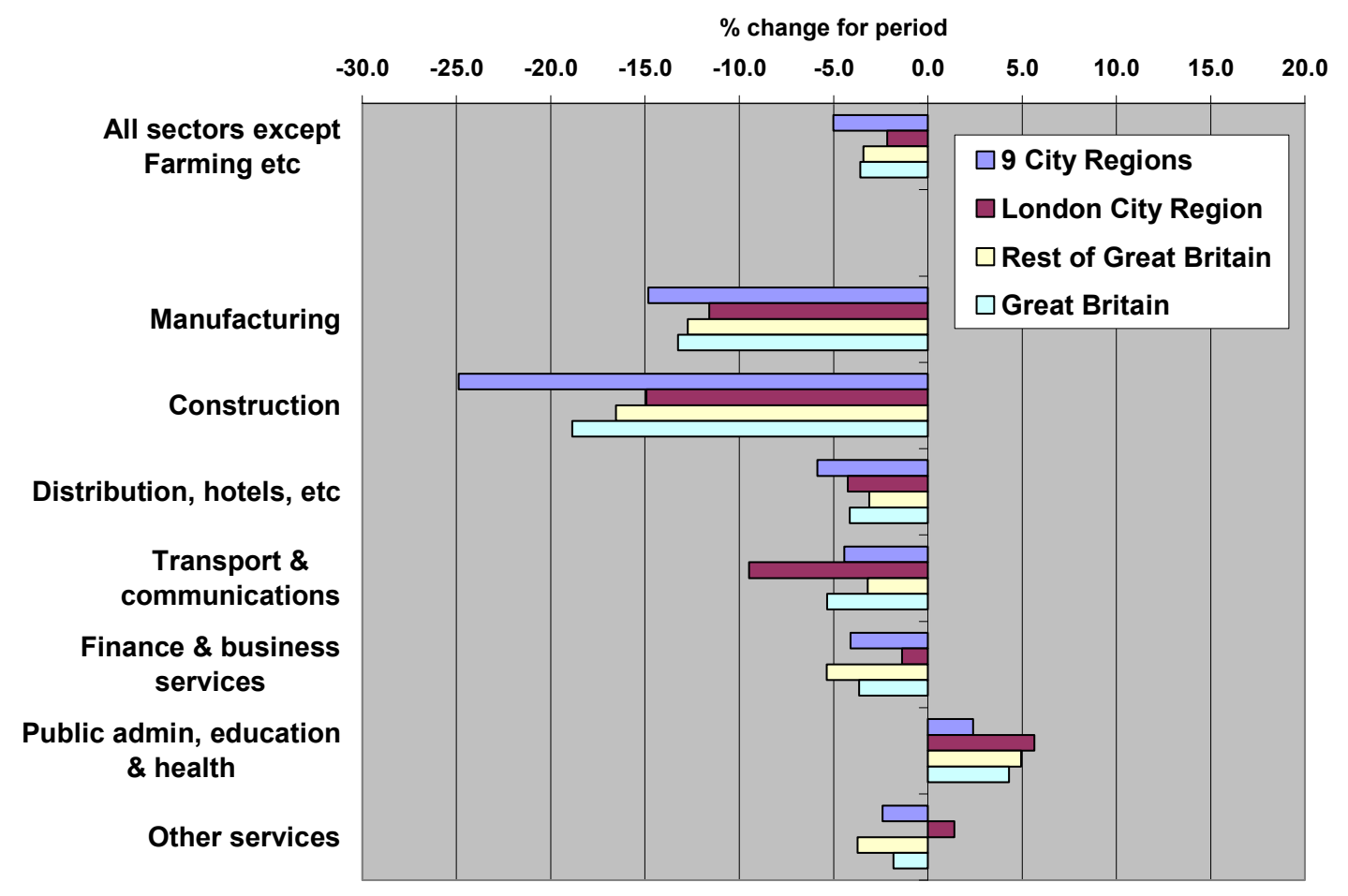

These differences represent 'differential shifts' in employment. Due to many detailed changes introduced by the 2007 Standard Industrial Classification, it is not possible to perform a full shift-share analysis on this data set, but what is clear from Table 2 and Figure 2 is the dominance of the 'national' element of change, accounting for 3.6 of 
the total 5.0 percentage points in total employment. However, due to overrepresentation of manufacturing and construction in the structural mix of city regions, only partially offset by that of the public sector, a negative 'structural shift' of a further 0.9 percentage points worsens the expected position of the 9 city regions. Their actual poor performance (the 'differential' shift, occasioned notably by the construction sector) is more important, as it accounts for the remaining balance of 1.5 percentage points. Manufacturing showed relatively even, though heavy, percentage decline in FTEs across the country, as first evident in the 1979-83 recession (Townsend, 1983).

\section{Comparison with the experiences of previous recessions}

We turn now to the longer term perspective and the question as to whether, following the substantial economic restructuring that they have undergone in recent decades, the second-order city regions fared better in the 2008-09 recession than might have been expected from their experience of previous ones, notably those of the early 1980s and early 1990s. This retrospective also provides the basis for considering whether the second-order city regions are likely to be more resilient than previously in the recovery that is hoped for over the next few years. In the separate commentaries on the experiences of recession and recovery that follow, it should be noted that, rather than use the official dating of the recessions based on the quarters when output was in decline (i.e. 1980-81 and 1990-91), we label them in relation to when employment was declining, using the years for which this can be best represented by the survey data (i.e. 1978-84 and 1989-93). Also, because our dataset on the second-order city regions can extend back only as far as 1984, for the purposes of looking back to 1978 we use a subset of these areas based on England's six metropolitan counties.

\section{Resilience in recessions}

In terms of the national picture, the relative severity of recessions varies according to whether using output or employment as the measure. The outstanding characteristic of the recent recession lies in the sharpness and depth of its decline in output rather than 
the overall size of its impact on the labour market (up till the faltering of the recovery in 2011, anyway). Its reduction in output of more than 7 per cent was only slightly less severe than in the Great Depression and markedly greater than the cutbacks in the early 1990s and early 1980s of 3 and 6 per cent respectively, yet FTE numbers were only 3.5 per cent lower in 2010 than in 2007 compared to falls of 6.9 and 8.3 per cent in 1989-93 and 1978-84. Reasons put forward to explain the smaller labour impact compared with the two earlier recessions include the departure of labour migrants back to their home countries and a greater unwillingness of employers to lose their higher-skilled staff than previously. However, by the start of 2012 'many accept these arguments as only part of the story, arguing that more fundamental explanations for low productivity are needed' (Giles and O'Connor, 2012).

Looking back first to the 1989-93 recession, which we can study on the same geography as for $2007-10$, this is the one where nationally the impact fell much more on employment than on output. In particular, employment in production fell by 14.1 per cent and output by 6.7, with respective falls of 2.7 and 1.1 per cent in services. While manufacturing played the leading absolute role in this recession, it was strongly accompanied by construction, with just a small decline in finance and business services. This is a similar recessional pattern to 2007-10 except that these sectors were then accompanied by reductions in a greater range of services.

Table 3 compares the geographical impact of the 1989-93 recession with the recent one, using the same basis as Table 2. For the second-order cities combined, its impact was greater than that of $2007-10$ by 1.7 percentage points. This upward shift, however, was only half of that recorded nationally and very much smaller than that for London, though on a par with the rest of the country. This is consistent with the evidence that, while it was the London region that was hardest hit in the early 1990s, it was the rest of the country and especially the second-order cities that suffered worst after 2007.

The recession of 1990-93 is of particular note because it damped down the 'regional problem', if only temporarily. At this time London showed more cyclical behaviour than the second-order city regions, where manufacturing played a relatively more prominent role. Among the latter, it is noticeable that, along with Leeds, Manchester 
and Bristol, the areas with problems recognized from the 1930s, Glasgow, Newcastle and Liverpool, saw a smaller contraction of FTEs than three of the post-1978 problem areas, Sheffield, Nottingham and Birmingham. Also noteworthy is the change-around between the two recessions in the relative performance of the city regions' cores and outer areas, the former being harder hit in 1989-93 but much less so in 2007-10, while the outer areas were knocked back nearly as much by the recent recession as in 198993.

Table 3. Impacts of two recessionary periods compared

\begin{tabular}{lrrr}
\hline City Region (CR) & $1989-93$ & $2007-10$ & \% point shift \\
\hline Great Britain & -6.9 & -3.5 & 3.3 \\
& & & \\
London CR & -10.7 & -2.2 & 8.5 \\
Non-CR & -5.0 & -3.4 & 1.6 \\
9 CRs & -6.7 & -4.9 & 1.7 \\
Bristol CR & & & \\
Leeds CR & -4.0 & 1.8 & 5.8 \\
Nottingham CR & -5.2 & -3.2 & 2.0 \\
Sheffield CR & -8.0 & -3.8 & 4.2 \\
Manchester CR & -9.6 & -4.3 & 5.3 \\
Newcastle CR & -6.7 & -4.5 & 2.3 \\
Liverpool CR & -2.7 & -5.3 & -2.6 \\
Glasgow CR & -7.2 & -5.5 & 1.7 \\
Birmingham CR & -5.4 & -8.0 & -2.6 \\
& -9.2 & -8.0 & 1.2 \\
9 Cities & & & \\
9 CR Remainders & -7.4 & -4.2 & 3.2 \\
\hline
\end{tabular}

Note: As for Table 2.

Source: calculated from BRES and its predecessors.

Comparison with the impact of the recessionary period spanned by the 1978-84 data is restricted here to the six former metropolitan counties (Figure 3). This earlier recession hit these manufacturing-dominated areas much harder than did the two subsequent ones. Indeed, it was this that pushed the West Midlands conurbation into identification with the 'North' of the UK, this suffering just as severely then as Tyne and Wear, Greater Manchester and South Yorkshire. Merseyside stands out with a loss of over one-fifth of its FTEs and even the least affected county, West Yorkshire, lost one in eight. This led to peaks of unemployment of 20.6 per cent on Merseyside and 19.9 in Tyne and Wear in 1986 (Townsend, 2010). These two areas had seen the worst rates of manufacturing decline in FTEs compared with the national rate of 4.9 
per cent, through continuing problems from deindustrialisation which had been underway since the late-1960s (Martin and Rowthorn, 1986).

Figure 3. Impacts of three recessionary periods compared, for 6 former Metropolitan Counties and Great Britain (source: calculated from BRES and its predecessors)

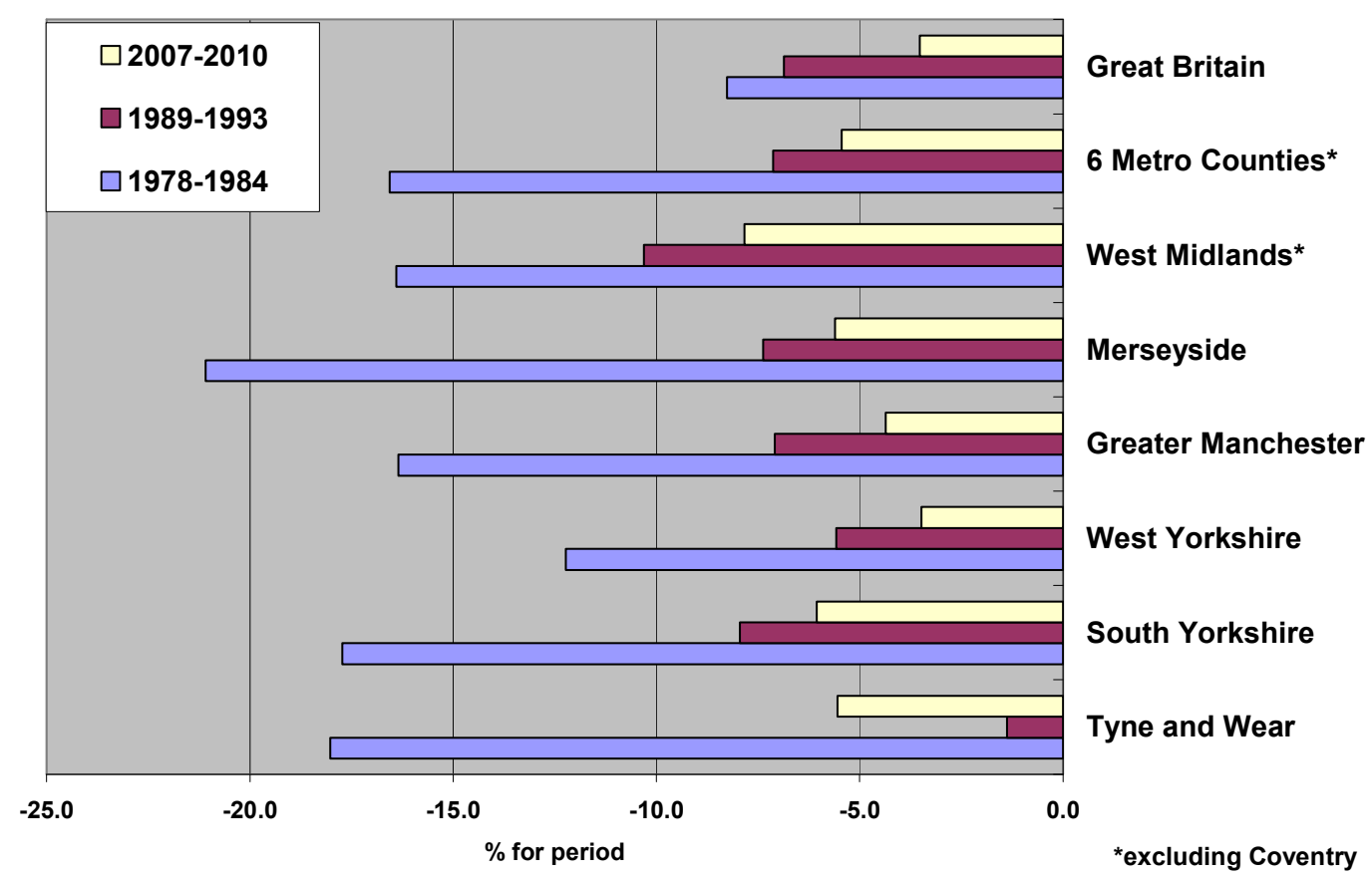

According to these two sets of analyses, therefore, the general picture is of these three recessions having progressively less impact on the FTEs of the second-order city regions, but this is the case only in absolute terms. Once allowance is made for the national trend of reducing impact (-8.3 per cent for 1978-84, -6.9 for 1989-93 and -3.5 for 2007-10), it is found that, while the gap between their performance and the national one shrank substantially between the first two of these recessions, it opened up again somewhat in 2007-10. Moreover, it was the long-standing problem areas based on Glasgow, Liverpool and Newcastle plus the Birmingham city region that performed least well in the latest recession both in actual growth rate and by comparison with their 1989-93 experience. On the other hand, this was partly to do with differences in the nature and regional incidence of the recessions, with each downturn having its own distinctive signature. 


\section{Resilience in upswings}

Martin (2012) critically shows how national employment levels had only just recovered their trend rate dating from before the 1979-83 recession when the further two recessions struck in both 1990 and 2008. But this national trend rate was far from attainment in the West Midlands and those Regions of the north which contain most of our city regions. Recession was followed from early-1993 onwards by one of the longest periods of sustained economic expansion on record, fuelled dominantly by the growth of banking and finance joined increasingly by related business services. In terms of 'resilience', by far the greatest 'recovery bounce' of our record is that of the London city region. As regards the performance of the second-order city regions during periods of national economic recovery, Figure 4 shows how the nine in aggregate fared after the 1989-93 recession and compares their trajectory with the London city region and the remainder of the country.

Figure 4. Change in FTE level, 1993-2010, for 9 City Regions, London City Region, Rest of Great Britain and Great Britain, $1993=100$ (source: calculated from BRES and its predecessors)

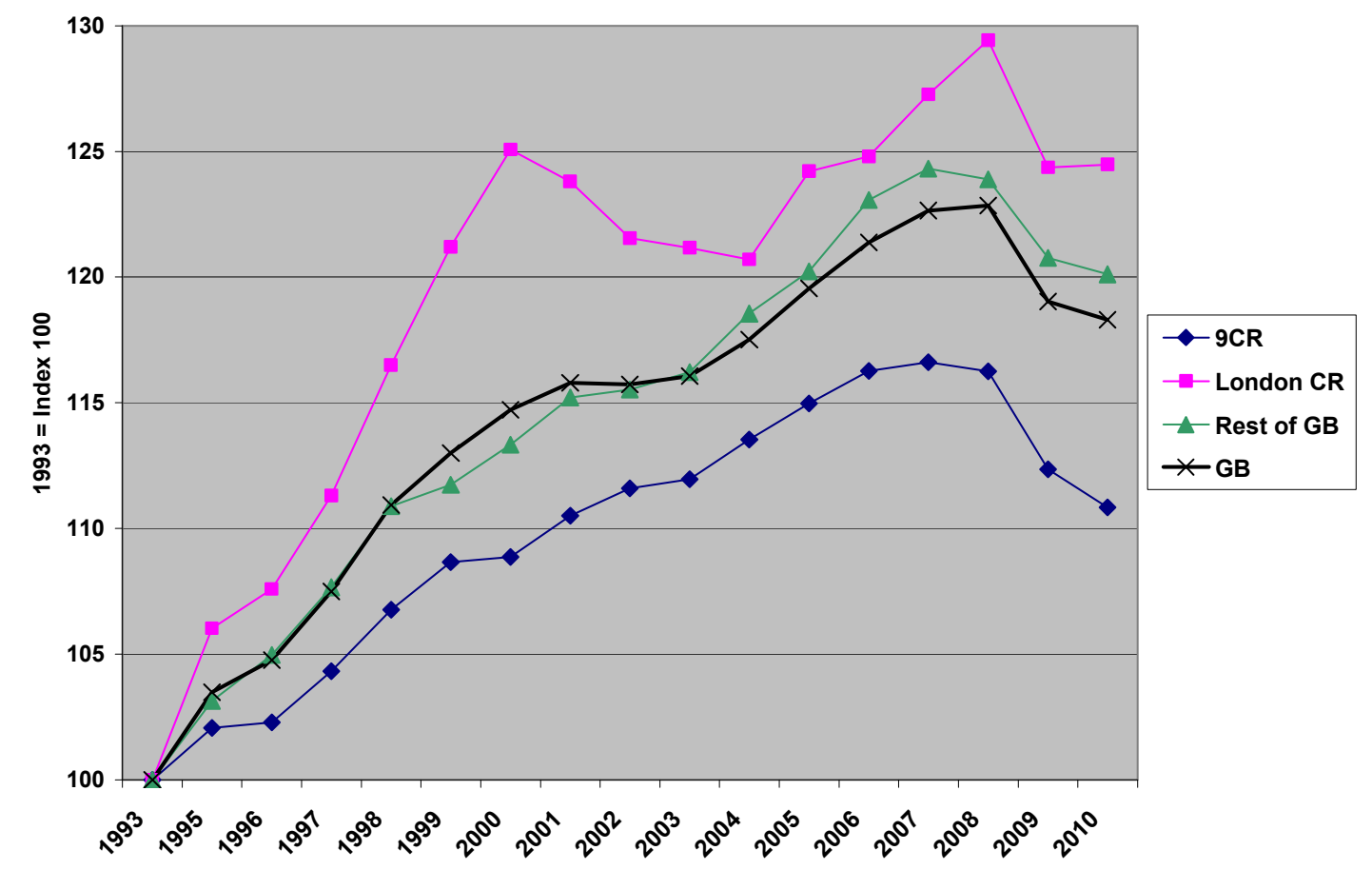

The second-order city regions certainly grew substantially over this period, with their aggregate level of FTEs reaching a peak in 2007 that was 16.6 per cent above their 
1993 level. Yet this was considerably short of the national upswing of almost 23 per cent before the next recession kicked in and the gains of around 24 and 29 per cent respectively for non-city-region Britain and the London city region, the latter being despite the shock of its 2001 dot-com recession, which explains the relative gain of the city regions against the national performance, 1998-2002 (Champion and Townsend, 2011). In fact, of the nine, only Bristol exceeded the national figure, with an uplift which peaked in 2009 at almost 27 per cent, not far short of London's. In second place among the nine, Leeds managed a gain of just over 19 per cent, while Liverpool was the lowest achiever but still an overall gainer at 8.5 per cent.

By comparison, the previous recovery was a much shorter-lived and more modest affair. Nationally FTEs had risen by just 5.8 per cent from their 1984 level before the next recession hit. In this case, it was non-city-region Britain that recovered most strongly, up by 9.1 per cent, and London least, up by just 2.7. Even so, the 9 city regions combined were not much higher than the latter and, at 3.4 per cent, well below average, with two of them - Liverpool and Sheffield - actually losing ground over this five-year national-recovery period.

An alternative measure of resilience in recovery is in terms of how quickly places managed to recoup their recession-period losses. In relation to the 1989-93 recession when the 9 city regions combined saw their FTEs fall by 6.9 per cent, their prerecession peak was not surpassed until 1999, two years later than non-city-region Britain which had been least impacted by that recession and one year later than London despite the latter being knocked back much more by that recession (see above). As for the second-order city regions individually, Bristol was the first to get back to its pre-recession peak (in 1996), followed by Leeds (1997), while Sheffield did not manage this until 2003 and Liverpool not until 2006, barely before the next recession hit.

As regards the longer-term impact of the earlier recession, we again have to refer to our data for the metropolitan counties because of our main series not extending back before 1984. Figure 5 compares their FTE trajectory with Great Britain's from 1978, before that recession impacted nationally, through to 2010, using selected years based on the recessions and dividing the long jobs boom of 1993-2007 into periods of 
similar length. This shows clearly the depth of the early-1980s recession and the limited ground that had been made up before the next recession hit. Nationally, it was not until 1998 that FTEs regained their 1978 level, but even more impressively only one of the six conurbations - West Yorkshire - had managed this feat even by the end of the long recovery in 2007 and even this had been brought back close to its 1978 level by 2010 . Admittedly, this will be presenting a bleaker picture compared to their full city regions because for most of the three decades spanned here the outermost parts of the latter were more resilient than the inner parts, but the former contain relatively few of the city regions' large workplaces and so including them would not alter the patterns much.

Figure 5. Change in FTE level, 1978-2010, for 6 former Metropolitan Counties and Great Britain, 1978=100 (source: calculated from BRES and its predecessors)

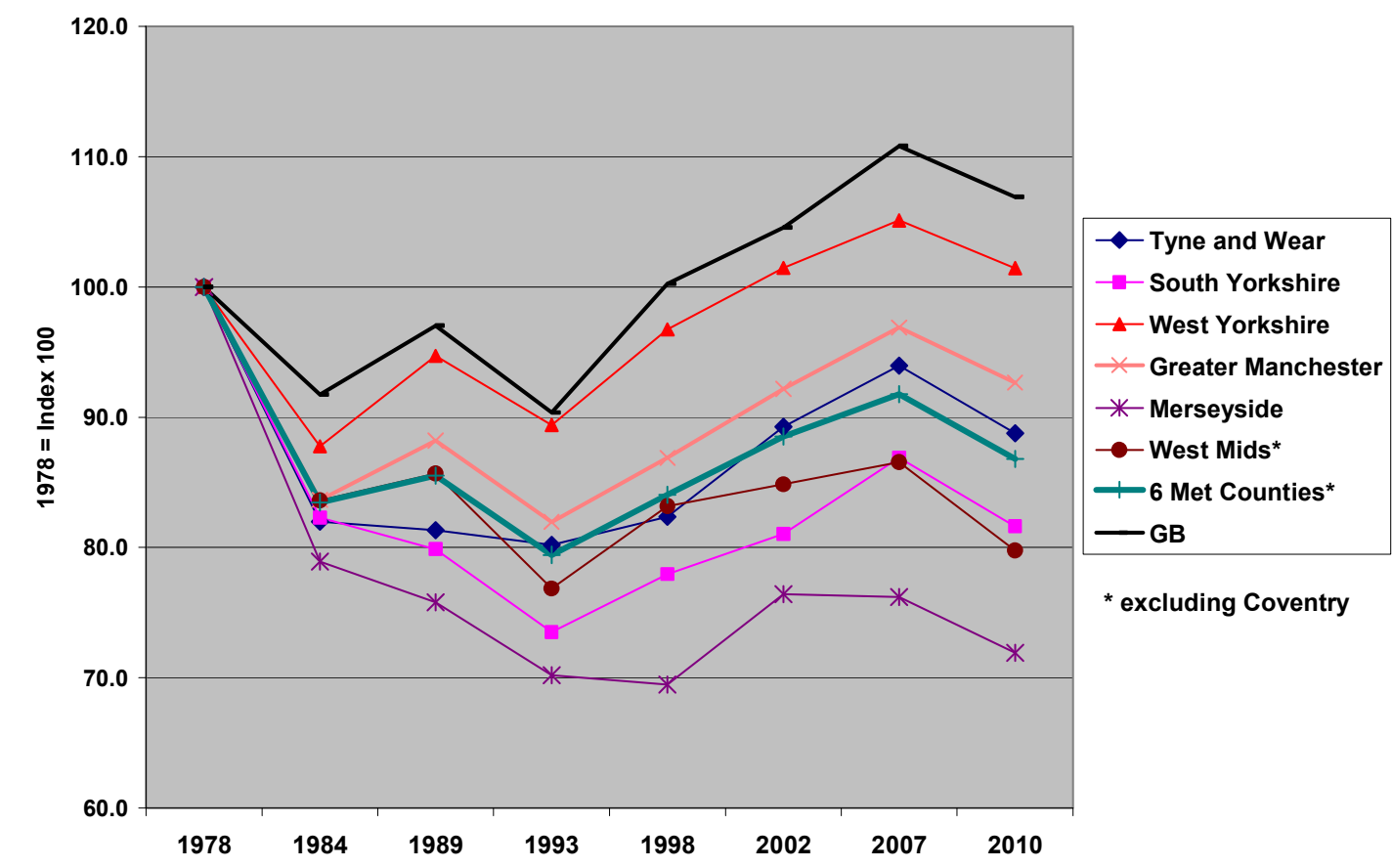

Finally, in the context of differences within the nine city regions, we focus on their cores (defined as their principal local authorities) versus the rest of their territories. In Figure 6, their post-1984 trajectories are shown for the nine combined and are also compared with those for London, where the core is defined as the 12 Inner London boroughs plus the City of London. For the nine city regions, the stronger long-term performance of their non-core parts is clear, though this was primarily the result of 
their quicker recovery after the early-1980s recession and their greater resilience during the early-1990s recession. Since the mid-1990s, however, the cores have clawed back ground somewhat, but not nearly as much as London's core has at its peaks. In fact, Inner London closed the gap with the city region's outer areas most rapidly during the last three years before the latest recession, when it was widening somewhat for the second-order city regions.

Figure 6. Change in FTE level, 1984-2010, for the cores and outer areas of 9 City Regions combined and London City Region, 1984=100 (source: calculated from BRES and its predecessors)

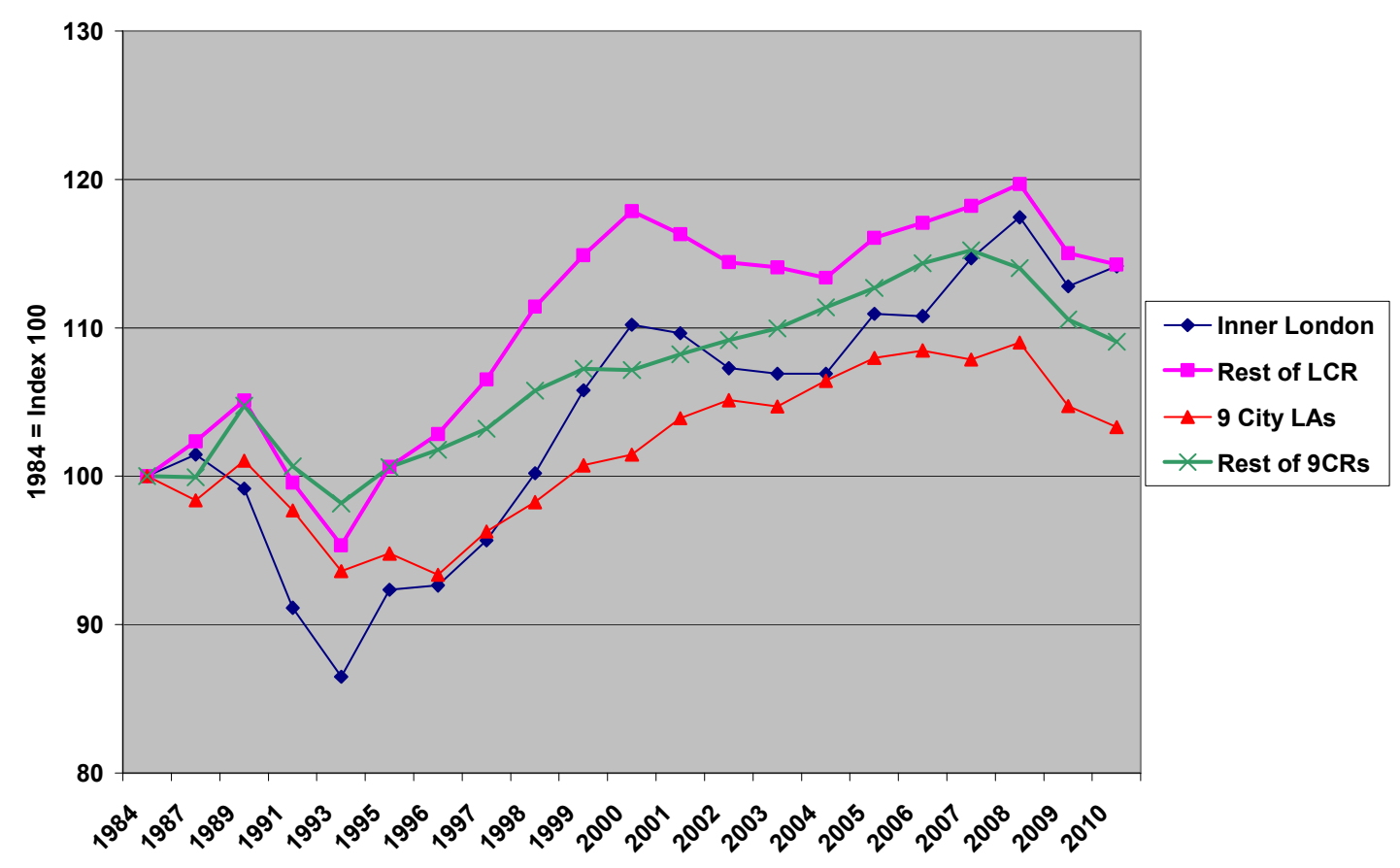

\section{Implications of post-recession industrial structures}

After our reference period ended in September 2010, labour market conditions were remarkably stable with employment growth showing a pattern familiar even from the 1930s (Law, 1981; Ward, 1988): it was the London, South East, East and East Midlands regions, along with Scotland, that were gaining jobs again. Nonetheless, the severity of the recent recession in output terms and the difficult conditions following on from it (with unemployment again increasing over the winter of 2011-2) appear to 
preclude the possibility of national growth recovering, let alone exceeding, the previous strong growth trend, or therefore returning to the previous trajectory of average year-on-year growth. Under the heading 'King bites bullet over lasting impact of recession', the Financial Times (Giles, 2011, page 3) recorded the public view of the Governor of the Bank of England that the damage done by the recession appeared permanent. Where then did the 9 city regions lie after successive recession and restructuring over the main period of this study?

While the period 1984 to 2010 saw the 9 city regions reduce their share of total GB FTEs from 31.0 to 28.6 percent, Table 4 also shows that they increased their shares of financial \& business services, and of public administration, education and health and transport and communication - substantiating many academic views on the role of modern services concentrating in cities. The first two of these sectors had long overtaken manufacturing as a source of employment, in fact the public sector group attained nearly 30 per cent of FTEs by 2010, above the national average, though the financial group still suffered under-representation.

Table 4. Changing sectoral composition of FTEs, 1984-2010, for nine city regions (9CR) compared with Great Britain (GB)

\begin{tabular}{|c|c|c|c|c|c|c|c|c|c|}
\hline \multirow[t]{2}{*}{ Sector } & \multicolumn{2}{|c|}{$\begin{array}{l}9 \text { City Regions } \\
(000 \mathrm{~s})\end{array}$} & \multicolumn{2}{|c|}{$\begin{array}{c}\text { Great Britain } \\
(000 \mathrm{~s})\end{array}$} & \multicolumn{2}{|c|}{$\begin{array}{c}9 \mathrm{CR} \text { as } \% \text { of } \\
\mathrm{GB}\end{array}$} & \multicolumn{3}{|c|}{$\begin{array}{c}\text { Each sector as \% of } \\
\text { all sectors }\end{array}$} \\
\hline & 1984 & 2010 & 1984 & 2010 & 1984 & 2010 & 9CR & GB & Diff \\
\hline Energy \& water & 259 & 55 & 595 & 189 & 43.5 & 29.4 & 0.9 & 0.9 & 0.0 \\
\hline & 1,795 & 74 & 5,138 & 2,3 & 34.9 & 31 & 12.0 & 10.8 & 1.1 \\
\hline & 325 & 326 & 993 & 1,089 & 32.7 & 30.0 & 5.3 & 5.0 & 0.2 \\
\hline $\begin{array}{l}\text { Distr } \\
\text { hote } \\
\text { Tran }\end{array}$ & 993 & 1,260 & 3,413 & 4,610 & 29.1 & 27.3 & 20.3 & 21.2 & -0.9 \\
\hline $\begin{array}{l}\text { Trans } \\
\text { comm } \\
\text { Finan }\end{array}$ & 346 & 373 & 1,287 & 1,291 & 26.9 & 28.9 & 6.0 & 6.0 & 0.1 \\
\hline $\begin{array}{l}\text { business services } \\
\text { Public admin, } \\
\text { education \& }\end{array}$ & 461 & 1,336 & 1,832 & 5,111 & 25.1 & 26.1 & 21.5 & 23.6 & -2.0 \\
\hline health & 1,167 & 1,827 & 3,932 & 5,933 & 29.7 & 30.8 & 29.5 & 27.3 & 2.1 \\
\hline Other services & 306 & 282 & 1,024 & 1,126 & 29.9 & 25.1 & 4.5 & 5.2 & -0.6 \\
\hline All sectors & 5,653 & 6,202 & 18,215 & 21,699 & 31.0 & 28.6 & 100.0 & 100.0 & 0.0 \\
\hline
\end{tabular}

Note: All sectors are included except Farming, forestry and fishing. "Diff" is the difference produced by subtracting GB from 9CR.

Source: calculated from BRES and its predecessor employment surveys.

Have therefore the long-term structural disadvantages of city regions largely been eliminated through de-industrialisation and restructuring? The answer here is that 
appearances are deceptive. Figure 3 showed that public sector jobs were the only expanding industrial division in 2007-10. If we took the rest of FTEs, in all the commercial or private sectors, on their own we find that the 9 city regions lost employment at a rate of 2.6 per cent p.a. compared with 1.7 otherwise and with a 1.4 per cent p.a. loss in the London city region and 2.1 in the country at large. In retrospect, it appears that an 'artificial' element of protection had been fed in through the maintenance of public sector jobs through the 2007-10 period (some of them originally fed in as replacements for lost industrial work).

The Comprehensive Spending Review (CSR) of the Coalition Government (HM Treasury, 2010) saw the necessity for a five-year programme of cuts in government expenditure and employment, seen to impact on areas with a greater dependence on these jobs. This was accompanied by a realisation (growing over the previous two years) that northern cities and regions had been strongly dependent on the public sector for employment and growth. The Review reverses the role of the public sector in the geography of employment change generally. In their autumn revision, the Office for Budget Responsibility (2011) increased their estimate of the number of jobs lost to 710,000 to $2016 / 7$, a reduction of 12.5 per cent in total 'general government employment' of 5.67 million (2011).

Several commentators applied assumed levels of reduction to public sector employment totals of all areas of Britain to assess the effect of the redundant staff being added to the existing unemployment totals. For instance, when applying a reduction of 25 per cent, Dorling and Thomas (2010) found projected unemployment rates of 20-23 per cent in Newcastle, Liverpool, Birmingham and Hull local authorities. We made more moderate assumptions in applying a similar procedure for a cut of 12.5 per cent in public sector jobs to the unemployment data for $2009 / 10$ as recorded at Table 1 (above). The results show a much greater than average increase in unemployment in the 9 core city local authority areas, from 11.0 to 14.5 percent. In their city regions as a whole, the greatest proportionate increases of unemployment lie in Liverpool, Glasgow and Newcastle, and the lowest in London, Manchester and Nottingham. Yet none of the changes alters the rank order of the three city regions with the highest and lowest unemployment rates, the former remaining Birmingham, Liverpool and Glasgow and Bristol, London and Leeds still with the lowest rates. 


\section{Conclusions}

This study of the impacts of the recent recession has found a greater variety of interrelated trends than might have been expected. One section managed to find some brighter spots in the performance of the 9 second-order city regions during the 200809 recession, notably their numbers in high-skill work growing faster than nationally, connected with their public sector employment growing (though below the average rate), their city-region cores in aggregate proving more resilient than their outer areas (possibly significant for the coalition government's policy focussing first on core cities), and Bristol's city region achieving overall FTE growth unlike not just the other 8 second-order cities but also London. Notwithstanding efforts at regeneration since the late-1990s, however, the wider picture was of these provincial city regions suffering a more severe impact than Great Britain as a whole. This is in stark contrast to the London city region which appears to have escaped much more lightly on most accounts, despite initial predictions of the reverse occurring owing to this recession being precipitated by the woes of the banking sector and attributable to the greater growth of professional jobs and to the government 'bail-outs' of the banks.

Furthermore, when a longer view is taken, some of the positive features for secondorder city regions are expected to be reversed, through what some regard as the sequel to the recession, the planned slimming down of the public sector between 2011 and 2017.

Our paper has found the city regions fairly tightly in the grip of national cyclical trends of recession and recovery, but generally performing worse than the country as a whole, tending over the long term to fall further behind the trajectory of pre-1980 growth rates, and to increase their levels of worklessness, notwithstanding the secular increase of FTEs from 1993 to 2007. There are variations, however, in the regularity of behaviour. Data for 1978-84 show the main English conurbations performing much further below the national average change rates than in 2007-10, but even then, as with the problems of the Birmingham city region, they showed the continuing weaknesses surviving from the new (post-1978) map of manufacturing decline $n$ (Townsend, 1983). London showed appreciably more cyclical behaviour between 1989 and 2002 than at other times, with the most remarkable recovery in this 
economic cycle. The public sector lifted the performance of second-order city regions from 1997 to 2010, including their peak of growth rates between 1998 and 2002 and the relatively strong performance of female employment and the core cities in 200710. We have to accept that each recession has had its own distinctive signature, spatially and otherwise, and though that of 2008-09 resembles more that of 1980-81 than 1990-91 (referring to the periods of output decline), this may not really help us imagine the future, as these previous ones were not (mainly) 'credit crunch' recessions and government support was not so much focused on the banks then.

\section{Appendix. The Employment Data Series}

The 1978-2010 data series on employees used in this paper is based on the Business Register Employment Survey and its three predecessors (see main text), and extends the manipulations reported for 1984-2007 in Champion and Townsend (2011). Constructing a consistent series is complicated by the fact that each of the four surveys used a somewhat different methodology, causing discontinuities in 1991, 1998 and 2008. There have also been changes within surveys, notably the reorganisation and/or updating of the Standard Industrial Classification (SIC) in 1980, 1992, 2003 and 2007 (leading to changes in the composition of sectors), the switch of reference date in 2006 to September from December (when counts were swelled by staff taken on in the pre-Christmas period) and in the frequency of the survey (every three years 1978-87, two-yearly till 1995, then annually). The treatment of jobs in the farming sector (collected separately via the Agricultural Census) has varied over time, including being totally suppressed from the district-level counts between 1989 and 1996. Lastly, the district-level geography used to define the 10 city regions has been affected by the reorganizations of local government in 1996-98 and 2009.

The steps taken to allow for these various discontinuities are as follows. In terms of geography, we used data for the local authority areas which were in force between 1998 and 2009 areas, as the National On-line Manpower Information System (NOMIS) provides counts for these retrospectively reconstituted back to 1984 and available also for 2010. Before 1981, the only 'local authority' data are for counties 
and Scottish Regions (both the best fit of the Job Centres for which the data was then reported), so those of our calculations that start in 1978 are restricted to the six English Metropolitan Counties. As regards industrial sector, we have adopted the longest reconstituted series available in NOMIS, namely SIC 1992 for 1991-2008, otherwise using the best fit of detailed components to match this grouping for before and after that period. Where breaks or overlaps occur, we have taken advantage of the availability of two sets of data for the same year, one on the new basis and the other on the previous one. Our series on employment change is therefore built up from each adjacent pair of survey years, drawing on the comparable data sets and calculating the annualized (compound) percentage change rate for inter-survey periods of more than one year. These annualized rates are then compounded to give the overall change for the periods reported in the paper. Finally, the varying treatment of farming jobs is dealt with by entirely omitting the industrial group comprising farming, fishing and forestry and, similarly, our series excludes self-employment throughout.

\section{References}

Bell, D. and Blanchflower, D. (2010), "UK Unemployment in the Great Recession", National Institute Economic Review, 214(1), pp. R3-R25.

Boschma. R.A. (2004), “Competitiveness of regions from an evolutionary perspective", Regional Studies, 38, pp. 1001-1014.

Brinkley, I. (2011), “A two-nation recovery”, http://www.theworkfoundation.com/blog/510/A-Two-Nation-Recovery

Centre for Cities (2012), Cities Outlook 2012, Centre for Cities, London.

Champion, A.G. (ed.), (1989), Counterurbanisation: The Changing Pace and Nature of Population Deconcentration, Edward Arnold, London.

Champion, A.G. and Townsend, A.R. (1990), Contemporary Britain: A Geographical Perspective, Edward Arnold, London.

Champion, T. and Townsend, A. (2011), “The fluctuating record of economic regeneration in England's second-order city-regions, 1984-2007”, Urban Studies, 48, pp. 1539-1562. 
Cheshire, P.C. (2006), "Resurgent cities, urban myths and policy hubris: what we need to know", Urban Studies, 43, pp. 1231-1246.

Christpherson, S., Michie, J. and Tyler, P. (2010), "Regional resilience: theoretical and empirical perspectives", Cambridge Journal of Regions, Economy and Society, 3, pp. 3-10.

Clayton, N. (2011), "The spatial impacts of recession", in D. Bailey and C. Chapain (eds) The Recession and Beyond, Routledge, London, pp 27-44.

Coe, N.M. and Jones, A. (eds) (2010), The Economic Geography of the UK, Sage, London.

Core Cities Group (2004), Our Cities Are Back, Third Report of the Core Cities Working Group, Office of the Deputy Prime Minister, London. http://www.corecities.com/dev07/Publications/OurCitiesAreBack8Nov.pdf Core Cities Group (2010), Core Cities Driving Recovery: A New Partnership with a New Government, Core Cities Group, Manchester.

CURDS (1999), Core Cities: Key Centres for Regeneration, Centre for Urban and Regional Development Studies, Newcastle upon Tyne.

Dawley, S., Pike, A. and Tomaney, J. (2010), “Towards the resilient region?”, Local Economy, 25(8), pp. 650-667.

Dorling, D. and Thomas, B. (2011), Bankrupt Britain: An Atlas of Social Change, Policy Press, Bristol.

ESPON (2011), Territorial Dynamics in Europe - The Creative Workforce, Territorial Observation No. 5, ESPON, Luxembourg.

ESRC (2009), Recession Britain, Economic and Social Research Council, Swindon, http://www.esrc.ac.uk/news-and-events/pressreleases/2853/New ESRC report on the impact of recession on peoples jobs businesses_and daily_lives_aspx

EU Regional Policy (2009), Promoting Sustainable Urban Development in Europe, European Commission, Brussels.

Fielding, A.J. (1993), "Migration and the metropolis: an empirical and theoretical analysis of inter-regional migration to and from South East England", Progress in Planning, 39, pp. 71-166.

Fingleton, B., Garretson, H. and Martin, R. (2012), "Recessionary shocks and regional employment: evidence on the resilience of UK regions", Journal of Regional Science, 52, pp. 109-133. 
Fothergill, S. and Gudgin, G. (1982), Unequal Growth: Urban and Regional Employment Change in the UK, Heinemann, London.

Giles, C. (2011), “King bites bullet over lasting impact of recession”, Financial Time, May 12, p. 3.

Giles, C. and O’Connor, M. (2012), "Reasons for poor productivity remain a puzzle", Financial Times, January 3, p. 3.

HM Government (2011), Unlocking Growth in Cities, Cabinet Office, London, http://www.dpm.cabinetoffice.gov.uk/sites/default/files dpm/resources/CO Unloc king\%(20GrowthCities acc.pdf

HM Treasury (2010), Spending Review 2010, The Stationery Office, London. ippr north (2009), The Impact of the Recession on Northern City-Regions, ippr north, Newcastle upon Tyne. http://www.ippr.org/publications/55/1731/the-impact-ofthe-recession-on-northern-city-regions?siteid=ipprnorth

Krugman, P. (1996), The Self-Organising Economy MIT Press, Cambridge MA)

Law, C.M. (1981), British Regional Development since World War I, Methuen, London.

Lee, N. (2009), Financial Services, the Middle Classes and the South: What Explains the Geography of the Recession?, Work Foundation, London, http://www.theworkfoundation.com/DownloadPublication/Report/221_Recession \%(20Impact $\%(20$ Paper\%(20(2).pdf

Lee, N., Morris, K. and Jones A. (2009), Recession and Recovery: How UK Cities Can Respond and Drive the Recovery, Work Foundation, London.

Leunig, T. and Swaffham, J. (2008), Cities Unlimited: Making Urban Regeneration Work, Policy Exchange, London).

Lewis, J. and Townsend, A. (eds) (1989), The North-South Divide: Regional Change in Britain in the 1980s, Paul Chapman Publishing, London.

LSE (2011), “The economic recession - why London escaped lightly”, London Briefing, http://www2.1se.ac.uk/geographyAndEnvironment/research/london/events/HEIF/ HEIF4b_10-11\%(20-newlondonenv/briefs/gordon.pdf

Martin, R. (2012), "Regional economic resilience, hysteresis and recessionary shocks", Journal of Economic Geography, 12, pp 1-32.

Martin, R. and Rowthorn, R. (1986), The Geography of Deindustrialisation, Macmillan, Basingstoke. 
Martin, R. and Sunley, P. (2006), "Path dependence and regional economic evolution”, Journal of Economic Geography, 6, pp. 396-437.

Martin, R. and Sunley, P. (2007), "Complexity thinking and evolutionary economic geography", Journal of Economic Geography, 7, pp. 573-601.

Morton, A. (2011), Cities for Growth: Solutions to Our Planning Problems, Policy Exchange, London.

ODPM (2006), State of the English Cities. Urban Research Summary 21, Office of the Deputy Prime Minister, London.

Office for Budget Responsibility (2011), Economic and Fiscal Outlook, http://cdn.budgetresponsibility.independent.gov.uk/Autumn(2011EFO_web_versi on138469072346.pdf

ONS (2011), "The impact of the recession”, Regional Trends, 43, pp. 1-64, http://www.ons.gov.uk/ons/search/index.html?newquery=impact + of + the + recessio $\underline{n}$

Parkinson, M., Champion, T., Evans, R., Simmie, J., Turok, I., Crookston, M., Katz, B., Park, A. et al, (2006), State of the English Cities, Volume 1, Office of the Deputy Prime Minister, London.

Rogers Report (1999), Towards an Urban Renaissance: Final Report of the Urban Task Force, Department of the Environment, Transport and the Regions, London. Rowthorn, R. (2010), "Combined and uneven development: reflections on the NorthSouth divide" Spatial Economic Analysis, 5, pp. 363-388.

Scott, A.J. (ed.)(2001), Global City-Regions: Trends, Theory, Policy, Oxford University Press, Oxford.

Smith, D. (1989), North and South: Britain's Economic, Social and Political Divide, Penguin, London.

Townsend, A. (1983), The Impact of Recession on Industry, Employment and the Regions, Croom Helm, Beckenham.

Townsend, A. (2010), "Continuity \& change in the impacts of recession seen through city regions", Regions, 278, pp. 25-27.

Ward, M. (2011), Rebalancing the Economy: Prospects for the North, Smith Institute, London.

Ward, S.V. (1988), The Geography of Interwar Britain, Routledge, London.

Wickham, M. (2010), London's Labour Market in the Recent Recession, GLA Economics Working Paper 44, Greater London Authority, London. 
Work Foundation (2010), Past Recessions: What Are the Lessons for Regeneration in the Future?, Regeneration Momentum Research Paper 1, The Northern Way, Newcastle upon Tyne.

http://www.thenorthernway.co.uk/downloaddoc.asp?id=760

Work Foundation (2011), "Centrally-led growth policy holding back cities outside London", http://www.theworkfoundation.com/Media/Press-

$\underline{\text { Releases/602/Centrallyled-growth-policy-holding-back-cities-outside-London }}$ 


\section{BIS Department tor abinines Innovation \& Skills}

\section{Spatial Economics Research Centre (SERC)}

London School of Economics

Houghton Street

London WC2A 2AE

Tel: 02078523565

Fax: 02079556848

Web: www.spatialeconomics.ac.uk

SERC is an independent research centre funded by the Economic and Social Research Council (ESRC), Department for Business Innovation and Skills (BIS) and the Welsh Assembly Government. 